\title{
ON SOME BOUNDS OF OSTROWSKI AND ČEBYŠEV TYPE
}

\author{
Faroog Ahmad, P. Cerone, S. S. Dragomir and N. A. Mir
}

\begin{abstract}
Making use of an identity of Dragomir and Barnett, proved in [13] [published in $J$. Indian Math. Soc. (N.S.), 66 (1999), No. 1-4, 237-245], some new Ostrowski and Čebyšev type inequalities involving two functions have been developed. Bounds obtained for the new established Ostrowski and Čebyšev type inequalities are of interest and are better than the bounds available in the literature for these type of inequalities.
\end{abstract}

Mathematics subject classification (2010): 26D15, 26D10.

Keywords and phrases: Ostrowski type inequalities, Čebyšev type inequalities, integral inequalities.

\section{REFERENCES}

[1] G. A. Anastassiou, Ostrowski type inequalities, Proc. Amer. Math. Soc., 123, 12 (1995), 37753781.

[2] N. S. Barnett, C. Buşe, P. Cerone And S. S. Dragomir, Ostrowski's inequality for vectorvalued functions and applications, Comput. Math. Appl., 44, 5-6 (2002), 559-572.

[3] K. Boukerrioua And A. Guezane-LAKoud, On generalization of Čebyšev type inequality, J. Ineq. Pure and Appl. Math., 8, 2 (2007), Art. 55.

[4] P. L. ČEBYŠEV, Sur les expressions approximative des integrals par les auters prises entre les mêmes limites, Proc. Math. Soc. Charkov, 2 (1882), 93-98.

[5] J. De La Cal and J. CÁRCAmo, A general Ostrowski-type inequality, Statist. Probab. Lett, 72, 2 (2005), 145-152.

[6] P. CERONE, On relationships between Ostrowski, trapezoidal and Čebyšev identities and inequalities, Soochow J. Math., 28, 3 (2002), 311-328.

[7] P. CERONE, A new Ostrowski type inequality involving integral means over end intervals, Tamkang J. Math., 33, 2 (2002), 109-118.

[8] P. CERONE, Approximate multidimensional integration through dimension reduction via the Ostrowski functional, Nonlinear Funct. Anal. Appl., 8, 3 (2003), 313-333.

[9] S. S. DRAGomir, A refinement of Ostrowski's inequality for absolutely continuous functions and applications, Acta Math. Vietnam, 27, 2 (2002), 203-217.

[10] S. S. Dragomir, Ostrowski type inequalities for isotonic linear functionals, J. Inequal. Pure Appl. Math., 3, 5 (2002), Article 68.

[11] S. S. DRAGOMIR, A weighted Ostrowski type inequality for functions with values in Hilbert spaces and applications, J. Korean Math. Soc., 40, 2 (2003), 207-224.

[12] S. S. DRAGOMiR, An Ostrowski like inequality for convex functions and applications, Rev. Mat. Complut., 16, 2 (2003), 373-382.

[13] S. S. DRAGOMIR AND N. S. BARNETT, An Ostrowski type inequality for mapping whose second derivatives are bounded and applications, J. Indian Math. Soc. (N.S.), 66, 1-4 (1999), 237-245.

[14] S. S. Dragomir And Th. M. Rassias (Eds.), Ostrowski Type Inequalities and Applications in Numerical Integration, Kluwer Academic Publishers, Dordrecht, 2002.

[15] S. S. Dragomir AND S. WANG, An inequality of Ostrowski-Grüss type and its applications to the estimation of error bounds for some special means and for some numerical quadrature rules, Computers Math. Applic., 33 (1997), 15-20.

[16] A. Florea AND P. C. Niculescu, A note on Ostrowski's inequality, J. Inequal. Appl., 5 (2005), 459-468. 
[17] G. GRÜSs, Über das maximum des absoluten Betrages von $\frac{1}{b-a} \int_{a}^{b} f(x) g(x) d x-\frac{1}{(b-a)^{2}} \int_{a}^{b} f(x) d x$ $\int_{a}^{b} g(x) d x$, Math. Z., 39 (1935), 215-226.

[18] D. S. Mitrinović, J. PeČarić And A. M. FinK, Inequalities Involving Functions and their Integrals and Derivatives, Kluwer Academic Publishers, Dordrecht, 1991.

[19] D. S. Mitrinović, J. PeČArić And A. M. Fink, Classical and New Inequalities in Analysis, Kluwer Academic Publishers, Dordrecht, 1993.

[20] A. Ostrowski, Über die Absolutabweichung einer differentiebaren funktion van ihrem Integralmittelwert, Comment Math. Helv, 10 (1938), 226-227.

[21] B. G. PACHPATTE, New Ostrowski type inequalities for mappings whose derivatives belong to $L_{p}-$ spaces, Demonstratio Math., 37, 2 (2004), 293-298.

[22] B. G. Pachpatte, On a new generalization of Ostrowski's inequality, J. Inequal. Pure Appl. Math., 5, 2 (2004), Article 36.

[23] B. G. PAChPATte, On Ostrowski-Grüss-Čebyšev type inequalities for functions whose modulus of derivatives are convex, J. Inequal. Pure and Appl. Math., 6, 4 (2005), 1-14.

[24] B. G. PACHPATTE, On Čebyšev type inequalities involving functions whose derivatives belong to $L_{p}$ spaces, J. Inequal. Pure and Appl. Math., 7, 2 (2006), Art. 58.

[25] B. G. Pachpatte, On Čebyšev-Grüss type inequalities via Pečarić extensions of the Montgomery identity, J. Ineq. Pure and Appl. Math., 7, 1 (2007), Art. 11.

[26] J. PeČARIĆ, On the Čebyšev inequality, Bull. Şti. Tehn. Inst. Politech. "Traian Vuia", Timişoara (Romania), (25)(39), 1 (1980), 5-9. 